\title{
The Flora of Stewart Island (New Zealand): a Study in Taxonomic Distribution.
}

\author{
BY \\ J. C. WILLIS, M.A., Sc.D., \\ European Correspondent, Botanic Gardens, Rio de Janeiro.
}

\section{With two Maps and fourteen Tables in the Text.}

$\mathrm{T}$ this paper I shall put together a few notes upon the flora of Stewart Island, the southernmost of the main chain of the New Zealand islands proper. I have carried on this study by the aid of my hypothesis of age and area, which indicates many new directions in which to search for facts that have hitherto passed unnoticed. My former predictions as to composition and distribution made by its aid have been so successful, that in this paper I have adopted entirely the method of prediction and subsequent verification, giving fourteen different predictions about the plants of Stewart Island. The composition of the flora is first dealt with, and its geographical and other relationships. The subject of the probable invasions of New Zealand by plants, commenced in my last paper, is then followed up, in so far as the relationship of Stewart Island to these invasions is concerned, and it will be continued in papers on the floras of the more outlying islands.

In publishing this series of papers on the geographical distribution of the New Zealand flora I am sometimes accused by botanists in Europe of trespassing upon a line of work which various New Zealand botanists have made peculiarly their own. These investigators have a real knowledge of the local conditions, whereas I possess none, and are turning out work of great value and importance, upon which I should not dream of trespassing. But I may be permitted to point out that their work is concerned with ecological, not with taxonomic, distribution, and it is to the latter that age and area refers. The two lines of work are really very distinct, and have comparatively little overlap. What is beginning to come out with great clearness from the study of age and area is that, given fairly uniform conditions, such as one finds in New Zealand, the distribution of the flora about the country, so far as the area occupied by the different species is concerned, is governed almost entirely by the law of age and area. The 


\section{Willis.-The Flora of Stewart Island (New Zealand):}

mere fact that one can make so many predictions about any of the floras of the New Zealand region, and find, on verification of the facts, that they are justified, is alone sufficient to show this. The principal cause that interferes with the uniformity of the action of age and area is the presence of actual barriers, such as Cook's Strait, Foveaux Strait, the central mountain chain, the sea dividing New Zealand from the outlying islands, and so on, but within New Zealand the actual ecological barriers, which might easily alter very largely the distribution of species if they were of sufficient breadth and width, do not seem to affect the question of area occupied, save in quite a minor degree. The plants are locally distributed, within the area which is assigned to them by the passage of time, in accordance with their reactions to the various ecological factors which are operative there. But ecology seems little concerned, so far as we can see, and so far as the figures of distribution give any guide, with the actual composition of the flora. Unfavourable ecological conditions may determine that a certain species shall not survive in a given place, so that it may reach what, in a list of modifying causes we have given in a previous paper $(6, \mathrm{p} .206)$, we have termed the climatic boundary, but which might better perhaps be termed in a more general way the ecological boundary. But otherwise ecology simply seems to make what it can, so to speak, of the floras with which it is provided by the mere action of phylogenetic descent and of time.

That the composition of the flora of Stewart is what it is, is largely due to the simple fact that certain species were at a certain distance from Stewart early enough to arrive there before the formation of Foveaux Strait, which cut it off from New Zealand proper. The figures of distribution give little evidence to show that many species have arrived since the formation of the strait, though there are a few, for example Urtica australis, which seem to be such cases. In general the distribution follows age and area with such closeness that one may make predictions on this basis alone, and find them often within perhaps five per cent. of accuracy.

It is worth while pointing out that by using the hypothesis of age and area one finds great numbers of new facts ready to be picked up, or explanations of what have hitherto been regarded as facts to be simply accepted as such. As one has as yet no guide as to their relative immediate importance, one must be content to collect them all, and no doubt they will in time prove their comparative values.

Stewart Island is a small island of 664 square miles, separated from South Island by Foveaux Strait, which at its narrowest has a breadth of sixteen miles, and at its shallowest (centre) a depth of fifteen fathoms (thirty metres). It would therefore seem not unreasonable to suppose that the separation from South Island was at a very remote period. This is confirmed by the fact that Stewart possesses local endemic species, confined 
to itself alone. In its relations to South Island it occupies a position like that of Ceylon in relation to South India.

It has the same indented rocky coast as South Island, and is similarly mountainous, Mt. Anglem reaching 3,200 feet. Geologically it is chiefly composed of archaean rocks, like those in the extreme south-west of South Island. It is clear from the soundings (see map) that it must have received its flora by way of New Zealand proper, and, being closer to the main islands, and probably not divided from New Zealand at an earlier period than the Chathams and Aucklands, it has received many more plants than they, and has double the flora of either of them.

Stewart Island being thus away from the general centres of distribution of the New Zealand flora, which in the previous paper we have seen to have been, one probably in the North Island, the other somewhere about the middle of the southern half of the South Island, a brief consideration of its relationships from the standpoint of age and area enables us to say that its flora will be composed of species which in comparison to those of New

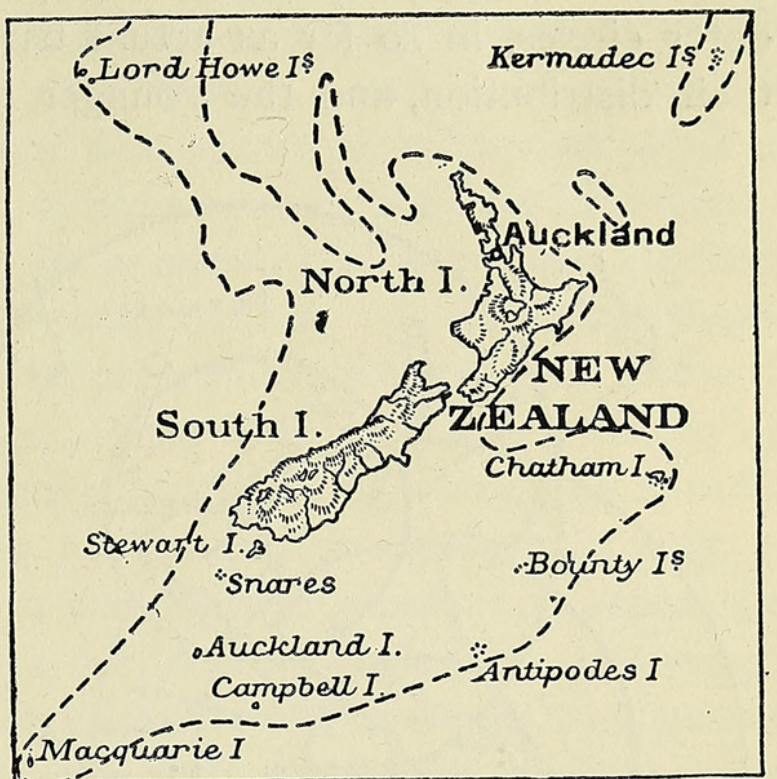

New Zealand and outlying islands. The dotted line is the 1,000 fathom limit. Zealand proper will be old. ${ }^{1}$ We shall work upon this as a fundamental fact and go on to study the flora by the method of prediction and verification.

\section{COMPOSITION OF THE FLORA OF SteWART ISLAND.}

As showing that age and area lends itself to prediction, we shall begin by endeavouring to predict as far as may be the actual composition of the flora, assuming that we know nothing about Stewart other than its position, but that we know the floras of New Zealand and the other outlying islands to the extent described by Cheeseman $(1,2)$.

To commence with the actual size of the flora: we have seen that the falling off in number of species from their zones of greatest concentration is fairly regular $\left(8, \mathrm{p} .343^{2}\right)$, and we should expect, if Stewart were in land connexion, that the flora would be about $55^{\circ}$, but as the formation of the strait must have been early enough to prevent many species from crossing which have since reached the strait from the north, we shall not expect so

1 The same conclusion follows almost as clearly from the usual interpretation of the hypothesis of Natural Selection.

${ }^{2}$ Species endemic to New Zealand and tslands are not given in this list. 
many, but perhaps 400 or less. In actual fact the flora is $3^{I} \mathrm{I}$, to which must be added 57 ferns. (Cf. Appendix, p. 42.)

In my last paper we saw that New Zealand probably received the bulk of its flora by two great invasions, one northern, within 400 miles from the north end of North Island, and the other southern, with its centre somewhere a little south of the middle of South Island. If we assume, for the sake of simplicity, that Auckland and Dunedin were the actual centres of these invasions, ${ }^{1}$ and draw circles round them, as done in the adjoining map, then it is clear that the older plants will be near the boundaries of the outer circles, in so far as actual barriers of sea have not interfered with their distribution, and the younger successively nearer to the centres. It

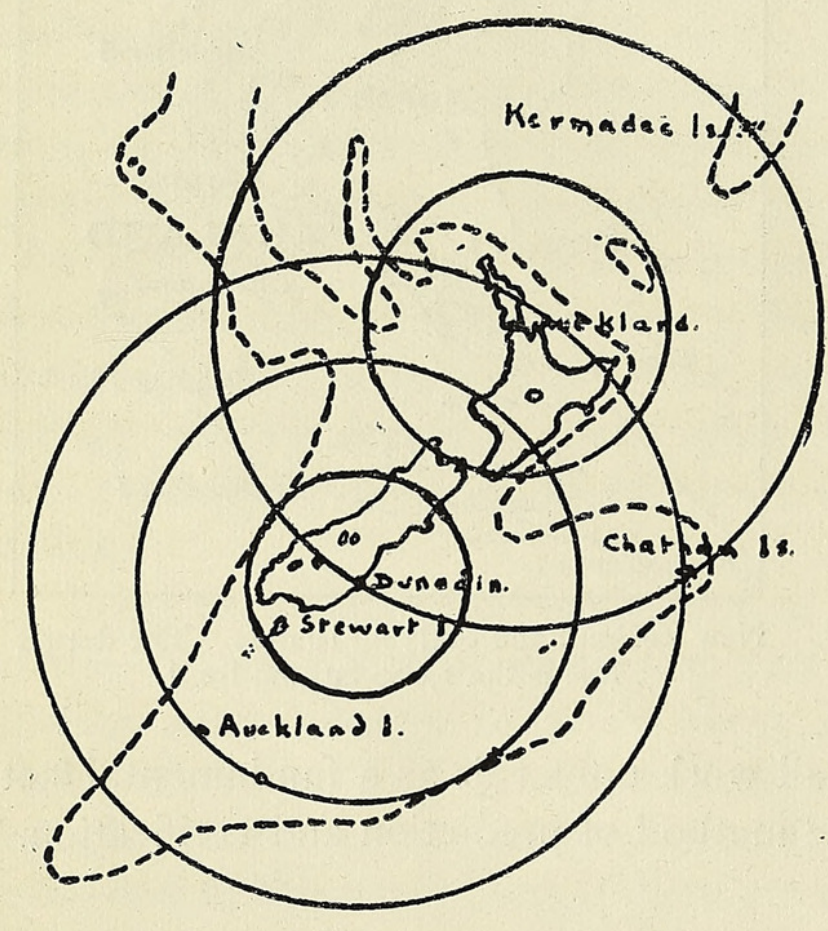

New Zealand and outlying islands. The dotted line is the $I, 000$ fathom limit. therefore follows (this thesis will be more fully developed in a later paper on the outlying islands) that the Chatham Islands should have a good deal in common with the Kermadecs of the older families, genera, and species, which can have reached both, and similarly much in common with the Aucklands, while of families, genera, and species that are sufficiently old in New Zealand all three groups of islands should possess representatives. The circle for the northern invasion that covers the Kermadecs and Chathams does not include Stewart, while that for the southern invasion which covers the Chathams and

Aucklands, or the Chathams and Campbell, does.

The general result of this prediction, then, so far as concerns Stewart, is that one will expect to find there all families, genera, and species that occur in the Kermadecs, Chathams, and Aucklands, or in the last two only. But as Stewart is nearer to the centres, one may expect to find there also a good many that have not reached the Kermadecs and Aucklands, or the Chathams and Aucklands, or even any of the outlying islands.

The Chathams, in their intermediate position, will probably contain a good many plants which do not reach the Aucklands. A straight line drawn from them to New Zealand reaches it at a point which is much

1 Examination of the map will show that displacement of the centres of the circles by 100 miles or so makes no difference to the arguments in this paper. 
farther from Stewart than from the Chathams. But if we draw a line direct from Stewart to the Chathams, and use it as the diameter of a circle, this circle cuts New Zealand near Lake Taupo in the North Island, and near Foveaux Strait. One will therefore expect to find, to a large extent, that those species which occur in the Chathams, and reach Lake Taupo as well as Foveaux Strait, will occur in Stewart, unless that island was cut off too early, a point as to which we have no information.

The southern invasion, as we shall see in the next paper, probably passed not very far from the Aucklands, and a circle with its centre in Dunedin and passing through Stewart also passes through the north end of South Island. One will therefore expect to find most Auckland species that reach the north end of South Island also occurring in Stewart, again of course in so far as an early cutting off of Stewart may not have interfered.

A family will very rarely arrive in a country as a group of genera simultaneously; some will arrive sooner than others. On the whole, therefore, a family with several genera will be older in the country than one with one, and the same will be true of genera, those with many species being on the whole the older. Now as the Stewart flora is mainly composed of older forms, we shall not go far wrong if we predict that it will contain most of those families that contain more than the average number of genera (in New Zealand proper), and those genera that contain more than the average number of species. This then may be added to the previous predictions. As, however, there are not so many families and genera with numbers above the average, this will not, probably, add very many.

We shall now give a complete list of the flora of Stewart, marking against each species and family the result of applying to it these different predictions. Everything that is actually predicted is printed in italics. As a rule when a genus or family is predicted some of the actual species are also predicted, but in the few cases where this does not happen, the genus or family is printed in italics, the species in roman type.

\section{TABLE I (and cf. p. 42).}

A occurring in the Kermadecs, Chathams, and Aucklands, or the two latter.

$\mathrm{B}$ occurring in the Chathams, and reaching Lake Taupo and Foveaux Strait.

C occurring in the Aucklands, and reaching the north end of South Island.

Families with five or more genera, and genera with five or more spp., are marked with to

RANUNCULACEAE A $\mathrm{B}$ C

Clematis + indivisa

Ranunculus + Lyallii

gracilipes

hivius

Kirkii (endemic St)

lappaceus

rivularis

acaulis
MAGNOLIACEAE

Drimys colorata

CRUCTFERAE +
Cardamine + hirsuta
Lepidium + oleraceum
tenuicaule
VIOLACEAE
Viola filicaulis

A B C

$x \times x$

$x \times x$

$x \times x$ 
Viola Cunninghamii

Melicytus ramiflorus lanceolatus

Hymenanthera ${ }^{\dagger}$ crassifolia

PITTOSPORACEAE

Pittosporum + Colensoi CAR YOPHYLLACEAE

Stellaria + parviflora

Colobanthus + Muelleri

Spergularia media

PORTULACACEAE

Claytonia australasica

Montia fontana

ELATINACEAE

Elatine americana

MALVACEAE

Plagianthus betulinus

TILIACEAE

Aristotelia racemosa fruticosa

Elaeocarpus Hookeriantıs

$$
\text { LINACEAE }
$$

Linum monogynum

$$
\text { GER ANIACEAE }
$$

Geranium † microphyllum sessiliflorum molle

Pelargonium australe CORIARIACEAE

Coriaria ruscifolia

$$
\text { ROSACEAE }
$$

Rubus australis

$$
\text { cissoides }
$$
schmidelioides

Geum + leiospermum

Acaenat sanguisorbae

SAXIFR AGACEAE +

Donatia novaezealandiae

Carpodetus serratus

Weinmannia racemosa

$$
\text { CR ASSULACEAE }
$$

Tillaea + moschata

$$
\text { diffusa }
$$

DROSERACEAE

Drosera $†$ stenopetala

$$
\begin{aligned}
& \text { Arcturi } \\
& \text { spathulata } \\
& \text { binata }
\end{aligned}
$$

II HALORRHAGIACEAE

aloragis + alata

$$
\text { tetragyna }
$$

depressa micrantha

Myriophyllum elatinoides intermedium pedunculatum

Gunnera t monoica

$$
\text { Hamiltoni }
$$

Callitriche Muelleri

MYR TACEAE

Leptospermum scoparium

Metrosideros † lucida hypericifolia

Myrtus pedunculata

A B C

\section{$\times$}

$x \times x$

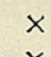

$x$

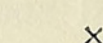

$x$

$x$

$x$

$x \quad x$

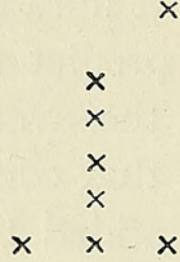

$\times \times x$

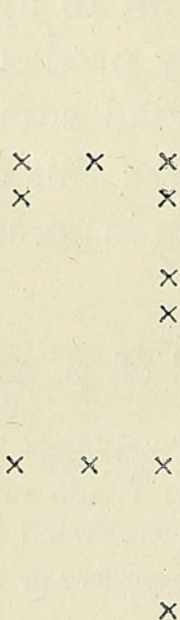

$x$

\section{ONAGRACEAE}

Epilobium $\uparrow$ Billardieranum pubens alsinoides rotundifolium linnaeoides

Fuchsia excorticata nummularifolium

$\begin{array}{rrr}A & B & C \\ \times & \times & x \\ x & \\ x & \\ x & \\ & x & \\ & & x \\ \times & x & x \\ & & x\end{array}$

Colensoi

FICOIDEAE

Tetragonia expansa

trigyna

UMBELLIFER AE †

Hydrocotyle † tripartita

$$
\text { americana }
$$

novaezealandiae

microphylla

asiatica

Actinotus novaezealandiae

Apium prostratum

Crantzia lineata

Aciphylla + Traillii

Ligusticum + intermedium flabellatum (endemic)

\section{$A R A L I A C E A E \uparrow$}

Aralia Lyallii

Panax $\uparrow$ simplex

Edgerleyi

Colensoi

Schefflera digitata

Pseudopanax + crassifolius

CORNACEAE

Griselinia littoralis

$$
\text { RUBIACEAE }
$$

Coprosma + lucida

$$
\text { rhamnoides }
$$

parviflora

acerosa

propinqua

foetidissima

Colensoi

cuneata

repens

Nertera depressa

dichondraefolia

setulosa

Asperula perpusilla

\section{COMPOSITAE +}

Lagenophora $\uparrow$ Forsteri petiolata

Brachycome $\uparrow$ pinnata

$$
\text { Thomsoni }
$$

Olearia $\nmid$ angustifolia

Traillii (endemic)

Colensoi

nitida

ilicifolia

avicenniaefolia

Celmisia + Sinclairii

petiolata

longifolia

linearis

sessiliflora

argentea

Gnaphalium + luteo-album japonicum 
Gnaphalium + collinum

Raoulia + Goyeni (endemic)

Helichrysum + bellidioides filicaule

Cassinia + Vauvilliersii fulvida

Craspedia uniflora

Cotula + coronopifolia australis Traillii (endemic) dioica

Abrotanella $\nmid$ muscosa (endemic)

Erechtites + prenanthoides

$$
\begin{aligned}
& \text { arguta } \\
& \text { scaberula } \\
& \text { diversifolia } \\
& \text { glabrescens }
\end{aligned}
$$

Senecio + bellidioides

$$
\text { Lyallii }
$$

lautus

Stewartii (endemic)

elaeagnifolius rotundifolius

Microseris Forsteri

Sonchus asper

$$
\text { oleraceus }
$$

STYLIDIACEAE

Phyllachne Colensoi

Dreostylidium subulatum

Forstera sedifolia

GOODENIACEAE

Selliera radicans

$$
C A M P A N U L A C E A E \dagger
$$

Pratia angulata

Wahlenbergia saxicola

ERICACEAE

Gaultheria † antipoda perplexa

\section{EPACRIDACEAE +}

Pentachondra pumila

Cyathodes + acerosa

$$
\text { empetrifolia }
$$

Leucopogon Fraseri

Archeria Traversii

Dracophyllum + Menziesii longifolium

Urvilleanum Pearsoni (endemic) rosmarinifolinm

PRIMULACEAE

Samolus repens

$$
\text { MYRSINACEAE }
$$

Myrsine + Urvillei

$$
\text { divaricata }
$$

nummularia

\section{LOGANIACEAE}

Mitrasacme novaezealandiae

$$
G E N T I A N A C E A E
$$

Gentiana + lineata

Grisebachii saxosa

Liparophyllum Gunnii

$$
\text { BORAGINACEAE }
$$

Myosotis t antaretica capitata

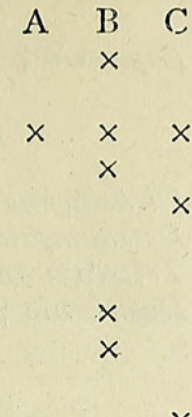

$\times \quad \times$

$x$

$x$

$\times \times x$

$\times$

$\times x \times$

$\times \times x$

$\times \quad x$

$\times$

$x$

\section{Lyperanthus antarcticus}

CONVOLVULACEAE†

A $\mathrm{B}$ C

Calystegia Soldanella

Dichondra brevifolia

SCROPHULARIACEAE' $\times \quad \times$

Glossostigma elatinoides

Veronica + salicifolia

amabilis

elliptica

buxifolia

Ourisia † macrophylla sessilifolia caespitosa

Euphrasia + Dyeri

LENTIBULARIACEAE

Utricularia $\uparrow$ monanthos

PLANTAGINACEAE

Plantago + Raoulii

Brownii

triandra

CHENOPODIACEAE†

Chenopodium + glaucum

Atriplex Billardieri

POL YGONACEAE

Rumex neglectus

Muehlenbeckia australis

CHLORANTHACEAE

Ascarina lucida

TH YMELAEACE AE

Pimelea + Lyallii

Drapetes Dieffenbachii Lyallii

URTICACEAEঋ

Urtica australis

ORCHIDACEAE†

Dendrobium Cunninghamii

Earina mucronata

suaveolens

Sarcochilus adversus

Thelymitra + longifolia uniflora

Microtis porrifolia

Prasophyllum Colensoi

Pterostylis + Banksii

australis

graminea

Caladenia Lyallii

bifolia

Chiloglottis cornuta

Corysanthes + oblonga

rivularis

rotundifolia

triloba

macrantha

Gastrodia Cunninghamii

IRID ACE AE

Libertia ixioides

pulchella

LILIACEAE†

Rhipogonum scandens

Enargea marginata

Cordyline $\downarrow$ australis

Asteira + linearis

nervosa $x$

$x$

$\times$

$x$ 
Phormium tenax

Bulbinella Hookeri

Arthropodium candidum

Herpolirion novaezealandiae

JUNCACEAE
Juncus + pallidus
effusus
bufonius
planifolius
antarcticus
novaezealandiae

Zostera nana

\section{CENTROLEPIDACEAE}

Centrolepis viridis

Gaimardia setacea

$$
\text { RESTIONACEAE }
$$

Leptocarpus simplex

Hypolaena lateriflora

\section{CYPERACEAE+}

Eleocharis + sphacelata

Scirpus + aucklandicus

$$
\text { cernueus }
$$

antarcticus

inundatus.

nodosus

Carpha alpina

Schoenus + pauciflorus axillaris nitens

Cladium + glomeratum Gunnii Vauthiera

Gahnia + procera

Oreobolus pumilio strictus

Uncinia + caespitosa australis leptostachya riparia rupestris filiformis

Carex + appressa echinata ternaria testacea lucida uncifolia comans litorosa dissita Solandri longiculmis (endemic) trifida

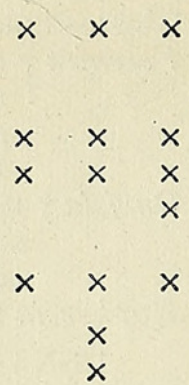

Lomaria † (Blechmum) Patersoni discolor vulcanica lanceolata dura

Banksii alpina capensis Asplenium + adiantoides

pulcherrimum

demisum

flabellatum

rufescens

stibtilissimum

minimum

tunbridgense

unilaterale bivalve

Lyallii

venosum

strictum

Cyathea medullaris

A $B \quad$ C

$\times \times x$

$x$

$\begin{array}{lll}\text { Dichelachne crinita } & & \times \\ \text { Deschampsia }+ \text { caespitosa } & \times & \times \\ \text { Trisetum aniarcticum } & \times\end{array}$

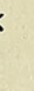

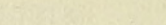

$x$

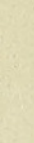




\begin{tabular}{|c|c|c|}
\hline & A & B \\
\hline Asplenium obtusatum & $x$ & $x$ \\
\hline $\begin{array}{l}\text { lucidum } \\
\text { bulbiferum }\end{array}$ & $x$ & $x$ \\
\hline $\begin{array}{l}\text { bulbiferum } \\
\text { flaccidum }\end{array}$ & $x$, & $\begin{array}{l}x \\
x\end{array}$ \\
\hline olystichum † aculeatum & $x$ & $x$ \\
\hline $\begin{array}{l}\text { capense } \\
\text { yopteris + hispida }\end{array}$ & & $x$ \\
\hline Polypodium + punciatum & $x$ & $x$ \\
\hline Billardieri & $x$ & $x$ \\
\hline
\end{tabular}

Polypodium + grammitidis

Cyclophorus serpens

Gleichenia + circinata dicarpa

Schizaea fistulosa Cunninghamii

Todea hymenophylloides superha
A $B$ C

$\times \times \times$

$x$

$\times$

$\times \quad \times$

$x$

A glance at the table will show that the species predicted form a very representative well-distributed assortment. There are 70 out of 200 Dicotyledons, or 35 per cent., 53 out of I I I Monocotyledons, or 47 per cent., and 43 out of 57 ferns, or 75 per cent. We may draw attention to Onagraceae, and especially Epilobium (all 6 species predicted), Coprosma (6 of 9), Orchidaceae, Juncaceae, and the ferns, including Pteris (all 3 species), Lomaria (7 out of 9), and Asplenium (all 5).

There remain unpredicted $x 88$ Angiosperms and I4 ferns. Ten of the former are local endemics which are dealt with below, and it might be possible to maintain that there is still room for relicts among the remaining 178. It is therefore of interest to trace their distribution in New Zealand. None have discontinuous areas, which is a feature that one might expect sometimes to show among relicts. Classifying them according to their range (two do not occur in New Zealand proper) we get :

TABLE II.

No. of Species.

$\begin{array}{ccc}\text { Class } & \text { I. } & 1,00 \mathrm{I}-\mathrm{I}, 080 \mathrm{~m} . \\ \text { 2. } & 88 \mathrm{I}-\mathrm{I}, 000 \\ 3 . & 76 \mathrm{I}-880 \\ \text { 4. } & 64 \mathrm{I}-760 \\ 5 . & 52 \mathrm{I}-640 \\ 6 . & 40 \mathrm{I}-520 \\ 7 . & 28 \mathrm{I}-400 \\ 8 . & 16 \mathrm{I}-280 \\ 9 . & 4 \mathrm{I}-160 \\ 10 . & 1-40\end{array}$

Mean rarity

Mean rarity for New Zealand

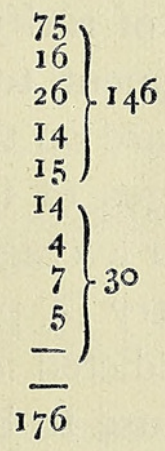

$3 \cdot 0$

$5 \cdot 5$

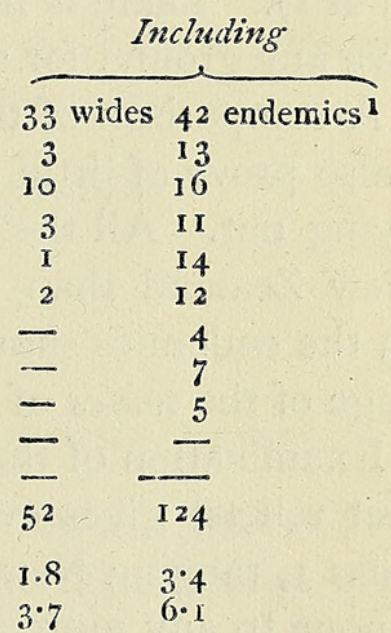

It is fairly evident that one can hardly consider as relicts the 146 species of classes I to 5 , which also reach the North Island, and that include 50 wides, some of which, like Spergularia media, are almost world-ranging. Thus there remain at most only 30 to choose from, or less than 10 per cent. of the flora of Stewart. It would be stretching too far an unproved hypothesis (that of the supposition that most species of very limited range are dying out) to include the $I_{4}$ in class 6 , which are mostly held up at

1 Endemic to New Zealand or New Zealand and islands. 
Cook's Strait, and which include two wides, so that there really only remain I6, in classes 7 to 9 . Of the 5 in class $9,4,{ }^{1}$ Gunnera Hamiltoni, Olearia angustifolia, Veronica amabilis, and especially Atropis novaezealandiae, are more or less closely confined to the coast, and I must leave it to the ecologists to settle whether they can be in any way regarded as relicts, or whether they are really coast species which arrived (or evolved) late, and by water carriage.

In any case, however, these last 16 species belong all of them to fairly large (old) genera (i. e. large in number of species in New Zealand). The genera of the 5 in class 9 contain in New Zealand 147 species, an average of almost 30 ; those of the 7 in class 8 contain 140 species, or an average of 20 ; those of class 7 are 4 with 38 species, or an average of $9 . \quad$ All are much above the average size of genera in New Zealand ( 4.2 species). It is obvious that these species belong to the same class of genera (the larger and older) as do the actual endemics of Stewart itself, which are dealt with below (Io genera, 249 species). As one approaches the centre of New Zealand one finds endemics in increasing numbers belonging to smaller and smaller genera, which, as we have seen above, are on the whole younger and younger genera. If these are relicts, then it is clear that the younger and smaller (in the country) a genus is, the greater its chance of giving rise to relicts; but the very awkward problem at once crops up, to explain why the relicts are crowded together in the centre of the main country of New Zealand, where there are also the most wides, as we have already shown $(6$, p. 20I). There is not, it seems to me, any evidence about these species to give any ground for supposing them relicts.

A comparison of the figures of rarity given at the bottom of Table II will also prove of little encouragement to the upholders of the hypothesis of dying out. All these species are on the average far more wide-ranging in New Zealand than the averages of the groups to which they belong. Even the endemics show a greater average range in New Zealand than the average of the wides of that country (7, p. 33I).

Examination of the I4 unpredicted ferns (where if anywhere one might expect relicts) gives even less cause to believe in extinction. Six belong to class I, ranging New Zealand from end to end, 3 to class 2, 5 to class 3, and none to any more localized class.

There yet remains one objection which may be brought up against the whole prediction and discussion given above. It may be said that I have drawn my predictions so wide that I have included the whole flora, and have simply picked out from this list the species belonging to Stewart. As the bulk of the predictions are based upon the actual floras of the other islands, this can hardly be the case, but it will be well in conclusion to give a list of

1 The fifth is Gentiana lineata, occurring in Longwood Range and Blue Mountains, Otago, and an unknown locality in Stewart. 
the species predicted for Stewart that are not recorded. Under prediction $A$ everything was exact. Under $B$ (species reaching the Chathams, Lake Taupo, and Foveaux Strait) the following have not been found in Stewart, though predicted as likely:

Plagianthus divaricatus (cf. p. 42)

Geranium dissectum

Sophora tetraptera

Potentilla anserina (cf. p. 42)

Epilobium pallidiflorum (cf. p. 42)

" chionanthum

" insulare (cf. p. 42)

Mesembryanthemum australe (cf. p. 42)

Hydrocotyle moschata

Oreomyrrhis andicola (cf. p. 42)

Daucus brachiatus

Coprosma robusta

, Cunninghamii

Erechtites quadridentata (cf. p. 42)

Lobelia anceps
Wahlenbergia gracilis (cf. p. 42)

Myosotis spathulata (cf. p. 42)

Calystegia tugoriorum (cf. p. 42)

Dichondra repens

Solanum nigrum

" aviculare

Myoporum laetum

Mentha Cunninghamii (cf. p. 42)

Salicornia australis

Polygonum serrulatum

Pimelea arenaria

Scirpus frondosus (cf. p. 42) americanus

Deyeuxia Billardieri (cf. p. 42)

These are twenty-nine in all, of which sixteen are wides, and there is no reason to suppose that their absence from Stewart is due to anything other than the fact that Foveaux Strait was formed before they reached so far south in their wanderings. It is noteworthy that the list contains only three Monocotyledons, though this group forms so large a proportion of the flora of Stewart (I I I of 3 II). ${ }^{1}$

Finally, under prediction $C$ (Auckland species reaching to Foveaux Strait and the north end of South Island) there were wrongly predicted :

Colobanthus Billardieri (cf. p. 42)

Rostkovia gracilis

Epilobium confertifolium

to which the same explanation may apply.

\section{General Features and Relationships of the Flora.}

We shall now go on to apply the method of prediction in greater detail, with the view of bringing out the general features and relationships of the flora of Stewart.

(I) As the family is older than the genus, the genus than the species, one will expect that in comparison with the flora of New Zealand proper a greater proportion of families will be represented than of genera, of genera than of species. Verification of this gives :

1 In a later paper I hope to deal with the distribution of the Monocotyledons, which shows many interesting points, e.g. a regularly diminishing percentage from one end of New Zealand to the other, and twice as great a percentage in the Aucklands as in the Kermadecs, with an intermediate figure in the Chathams, and so on. 
TABLE III.

$\begin{array}{lllc} & \text { Families. } & \text { Genera. } & \text { Species. } \\ \text { New Zealand } & 9 \mathrm{I} & 3^{29} & \mathrm{I}, 392 \\ \text { Stewart } & 54 \text { or } 59 \% & \mathbf{1} 54 \text { or } 46 \% & 3 \mathrm{I} \text { I or } 22 \%\end{array}$

(2) A family will rarely arrive as a group of genera simultaneously; some will arrive sooner than others. Therefore, on the whole, families with more than one genus in a given country will be older there than those with only one in that country, and may be expected to be better represented. Testing this, we get :

\section{TABLE IV.}

$\begin{array}{cc}\text { Family represented } & \text { In New Zealand. } \\ \text { in New Zealand by } & 36 \text { families } \\ \text { I genus } & \text { I5 } \\ 2 & \text { I5 } \\ 3 & \text { IO } \\ 4-5 & 9 \\ 6-10 & 6 \\ \text { over } 10 & - \\ & 91\end{array}$

\begin{tabular}{|c|c|}
\hline \multicolumn{2}{|c|}{$\begin{array}{l}\text { Represented in } \\
\text { Stervart by }\end{array}$} \\
\hline${ }_{6}^{3}$ families, & $\begin{array}{l}36 \% \\
40\end{array}$ \\
\hline 12 & 80 \\
\hline 9 & $9^{\circ}$ \\
\hline & 90 \\
\hline 6 & 100 \\
\hline 54 & 59 \\
\hline
\end{tabular}
Not represented there.
23 families
9
3
I
I
-
37

In other words, the most 'successful' families in New Zealand are the best represented in Stewart, and the proportion of families shows a steady increase with the increasing number of genera contained in them.

One may even push this into greater detail, and take the thirty-six families with one genus, dividing them according to the number of species in the genus, when one finds:

\section{TABLE $V$.}

\begin{tabular}{|c|c|c|}
\hline Genera. & No. of Species contained. & F'epresented in Stewart by \\
\hline 7 & 6 or more; 50 in all & 14 species, or $28 \%$ \\
\hline 5 & 3,4 , or $5 ; 17$ & 23 \\
\hline 24 & I or 2 & 10 \\
\hline
\end{tabular}

(3) One may extend the idea indicated in this last table, and make the same prediction about the genera as about the families, and say that those with most species in New Zealand will be the best represented in Stewart.

\section{TABLE VI.}
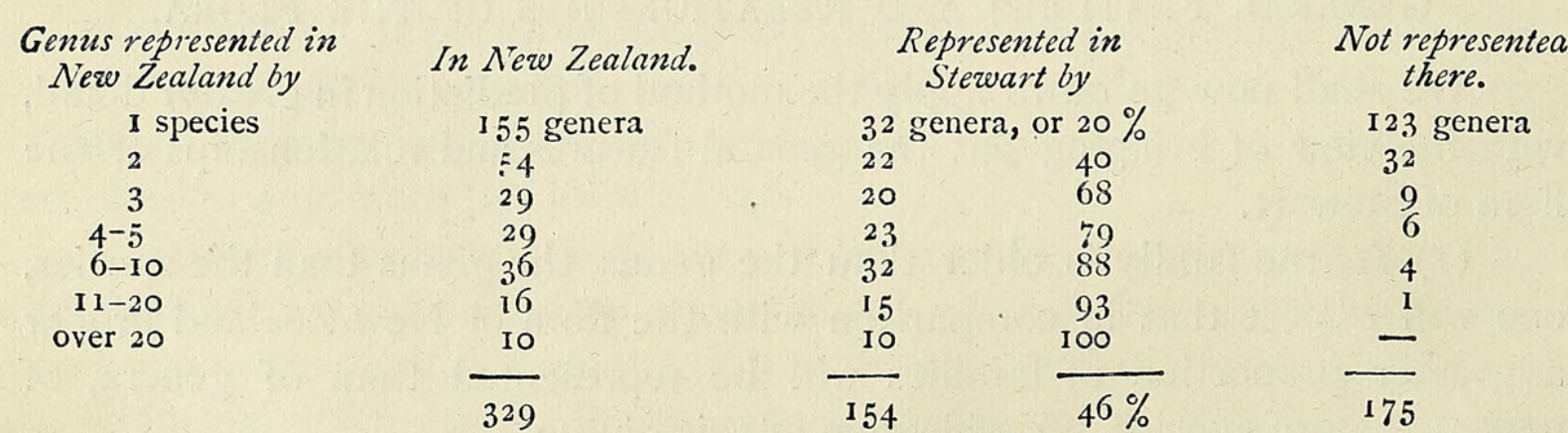

Thus, just as with the families, the proportion of genera represented in Stewart shows a steady increase with the increasing number of species in the genus, from 20 per cent. of those with one up to 100 per cent. of those with more than 20 species. 


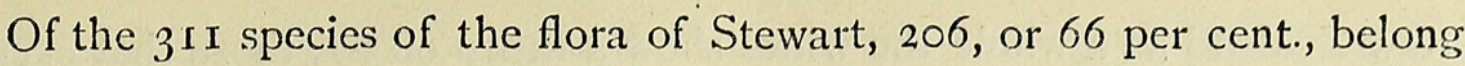
to the comparatively few genera that possess in New Zealand 5 or more species in the genus, the average number in a genus in New Zealand being $4 \cdot 2$.

On the hypothesis of Natural Selection, as usually interpreted, one would expect to find Stewart Island-an outlying island, small in area, simple in geological structure, with small flora and peopled by old speciesoccupied largely by plants unsuited to life in the crowded South Island, in fact a kind of refuge for the destitute. This expectation is vehemently contradicted by what we have just indicated. The genera of Stewart, as a glance at the list of the flora will show, are in reality what it has been the custom to call the 'successful ' genera of the neighbouring island, from which it must have received its flora. These genera are in reality simply those which were the first to arrive of their various affinity groups. The first 10 genera of the Stewart flora are represented in New Zealand by 103 species, or an average of 10.3 species per genus, against an average for New Zealand of $4 \cdot 2$. The last 10 have 70 species in New Zealand, or an average of $7 \cdot 0$. The 154 genera of Stewart contain in New Zealand 1,067 species, against 325 for the 175 unrepresented genera.

(4) The Stewart Island plants being old, we shall expect to find 'wides', which are the oldest forms, best represented among them.

\section{TABLE VII.}

Wides.

New Zealand as a whole Stewart Island
$30 \mathrm{I}$

III, or $36 \%$
Endemic to Nere Zealand or Nerv Zealand and Islands. 1,000 $187^{1}$, or $18 \%$

(5) One will expect to find the Stewart Island plants, as very old, very widespread in New Zealand:

\section{TABLE VIII.}

$\begin{array}{lcccc}\text { Class. } & \text { Range in Nerv Zealand. } & \text { Wiales. } & \begin{array}{c}\text { Endemic to } \\ \text { Nerw Zealand } \\ \text { and Islands. }\end{array} & \begin{array}{c}\text { Endemic to } \\ \text { Nere Zealand } \\ \text { only. }\end{array} \\ \text { I } & \text { I,00I-I,080 miles } & 8 \mathrm{I} & 37 & 48 \\ 2-4 & 64 \mathrm{I}-\mathrm{I}, 000 & 23 & 18 & 40 \\ 5-10 & 1-640 & -7 & \frac{8}{63} & \frac{36}{\mathrm{I} 24}\end{array}$

Thus 166 plants, or 55 per cent., belong to the first class, which ranges New Zealand from end to end. Even the species endemic to New Zealand alone show more in the first class than in classes 2, 3, and 4 put together, though in New Zealand as a whole the numbers in the first four classes are, $5^{2}, 60,59$, and $6 \mathrm{I}$.

If we calculate out the rarity in the usual manner, we find that while in

1 The remaining thirteen include the ten local endemics, and Aralia Lyallii, Urtica australis, and Poa foliosa, not found in New Zealand proper, and perbaps, or probably, water-borne. 
New Zealand as a whole the wides show a rarity of $3 \cdot 7$, those that occur in Stewart show I.7. As each unit of rarity represents 120 miles, this means that they range (in New Zealand) on the average 240 miles farther. Similarly the species endemic to New Zealand and the islands show 2.2 for Stewart against $2 \cdot 9^{1}$ for New Zealand as a whole, and the species endemic to New Zealand only show $3 \cdot 2$ against $6 \cdot 5$. In other words, they range on an average 796 miles against 400 , and even exceed in their range the average wide of New Zealand as a whole, which ranges only 736 miles. This is a feature which is quite impossible of explanation by aid of the doctrine of Natural Selection.

(6) As the ferns are probably older, Stewart should have proportionately more of them than New Zealand proper, but one must remember that the question of the ferns is complicated by the probability-amounting to practical certainty - that new wides may continue to arrive long after the barrier interposed by the sea has become practically impassable to more than a very few Angiosperms (8, p. 340).

\section{TABLE IX.}

\section{Wiles. Endemic to New Zealand Endemic to Nerw}

Ferns. Angiosperms. Ferns. Angiosperms. Ferns. Angiosperms.

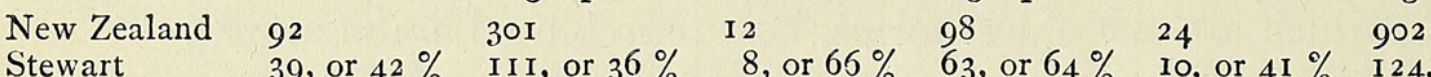

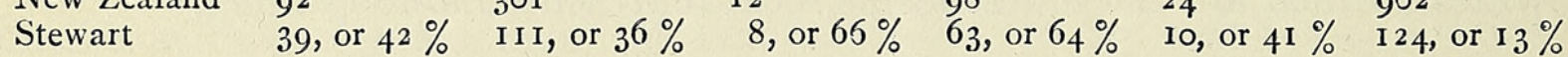

All the figures for ferns are higher than for Angiosperms, though there is considerable difference among them. The difference, however, is most marked in the New Zealand endemics, as would be expected.

(7) Stewart Island possesses Io species endemic to itself alone, and found nowhere else. As on the whole, as we have already pointed out, the largest families in New Zealand will be the oldest, we shall expect these endemics to belong to them (and cf. Appendix, p. 42).

\section{TABLE X.}

Family (in order of size in Nerv Zealand).

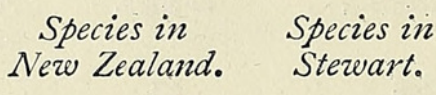

I. Compositae

2. Cyperaceae

3. Scrophulariaceae

4. Gramineae

5. Orchidaceae

6. Umbelliferae

7. Ranunculaceae

8. Rubiaceae

9. Onagraceae

10. Epacridaceae

Total Io families
203

\begin{tabular}{|c|c|}
\hline II 7 & 34 \\
\hline 109 & 9 \\
\hline 97 & $3^{\circ}$ \\
\hline 57 & $2 \mathrm{I}$ \\
\hline 54 & I I \\
\hline 45 & 8 \\
\hline 43 & I 3 \\
\hline $3 \mathrm{I}$ & 8 \\
\hline 28 & 10 \\
\hline
\end{tabular}

Endemics.

\{learia Traillii
Raoulia Goyeni
Cotula Traillii
Abrotanella muscosa
Senecio Stewartii
Carex longiculmis

1 For the reason why these species are more common than the average of the wides, see 7 , p. 33 I. 
Thus all the endemics are to be found in the ro largest families in New Zealand, and as a matter of fact in 6 of them, which contain in New Zealand 544 species (total for New Zealand, 9I families and I,30I species), and in Stewart 137 species (total for Stewart, 54 families and 3 I I species). They belong, that is, to the most 'successful' families in New Zealand. The great proportion belonging to Compositae is noticeable, and goes to indicate, with other parallel evidence that could be produced, that species are somewhat readily formed in this family.

(8) In the same way, one will expect the Stewart endemics to belong on the whole to the larger genera of New Zealand, and testing this, we find that Olearia has 35 species, Raoulia I7, Cotula I9, Abrotanella 7 (the nearest approach to the average of $4 \cdot 2$ ), Senecio 30 , Carex 54 , Danthonia I 3 , Ligusticum 18 , Ranunculus $3^{8}$, and Dracophyllum $\mathrm{I} 8$, a total of 249 species for 10 genera, or practically 25 each, almost six times the average for a genus in New Zealand.

Relationships of the Flora to those of the OUtlying Islands.

We shall now go on to deal with the relationship of the flora of Stewart to those of the Kermadecs, Chathams, and Aucklands, which (see maps) are islands outlying much farther from New Zealand proper, but at the same time islands that must have received the bulk of their flora either by way of New Zealand, as in the case of the Chathams more especially, or at any rate from the same invasions, as in the case of the Kermadecs (to some extent) and the Aucklands. As authority for these floras I shall continue to use Cheeseman's Flora (1), supplemented by his later lists in Chilton's 'Subantarctic Islands of New Zealand' (2).

Stewart Island lies in lat. $47^{\circ} \mathrm{S}$., the Aucklands in $51^{\circ}$, the Chathams in $44^{\circ}$, and the Kermadecs in $30^{\circ}$. The distance in a straight line from Stewart to the Aucklands is about 200 miles, to the Chathams about 700 miles, and to the Kermadecs about I,200 miles, including nearly the whole of New Zealand, which lies between. Stewart is chiefly archaean rocks, the Aucklands all of igneous origin (some parts granites and gabbros, but mostly volcanic), the Chathams schists, volcanic rocks, or tertiary sediments, and the Kermadecs entirely volcanic (4).

(9) It is clear from the maps, especially the second map on p. 26, that while the plants of Stewart Island are old in New Zealand, those of the other more outlying islands will be older, in general, whether they were derived from New Zealand, or whether they reached these islands on the way to New Zealand. One will therefore expect to find that Stewart has a large proportion of species in common with these different islands, and that they have a larger proportion of species in common with Stewart than they have with New Zealand as a whole, though in general they are neare: to New Zealand. Testing this, we find : 


\section{TABLE XI.}

Common to Stewart and Aucklands " New Zealand and A. ", Stewart and Chathams

" New Zealand and C.

" Stewart and Kermadecs

" New Zealand and K.

\begin{tabular}{|c|c|c|}
\hline & es, or 22 & $\%$ of flora of Stewart \\
\hline & 27 & $\begin{array}{l}\text { New Zealand } \\
\text { Stewart }\end{array}$ \\
\hline II 8 & & New Zealand \\
\hline 52 & 7 & $\begin{array}{l}\text { Stewart } \\
\text { New Zealand }\end{array}$ \\
\hline
\end{tabular}

That Stewart Island should have a great deal in common with the Aucklands might be expected, but that it should have proportionately so much more in common with the Chathams and the Kermadecs than has New Zealand, though the latter divides it from the Kermadecs, and is nearer to the Chathams, would never be expected on the older views as to distribution of species. This subject will be followed up in a subsequent paper on the outlying islands.

(Io) On examination of the map, it will be noticed that no circle can be drawn to include the Chathams and Aucklands without including Stewart, unless it be placed with its centre in an impossible depth of soundings. Unless, therefore, the times of separation from New Zealand of Stewart and these islands were very different, we shall expect to find that all species common to the Chathams and Aucklands also occur in Stewart:

\section{TABLE XII.}

Common to Chathams and Aucklands.

Dicotyledons
Monocotyledons
Ferns

\begin{tabular}{ll} 
I9 & 19 \\
I3 & 13 \\
I9 & 19 \\
\hline 51 & 51
\end{tabular}

(I I) If one draw a straight line from Stewart to the Chathams, bisect it, and use the point of bisection as the centre of a circle whose circumference passes through the islands mentioned, then it is evident that if at the time of dispersal of most species there was continuous land where the I,000 fathom line now runs, the species common to Stewart and the Chathams should in general have covered this circle, or so much of it as was above water. The circle cuts the North Island near Lake Taupo, at about $35^{\circ}$ miles from the North Cape, so that, except in so far as barriers caused by submergence of parts of the land, or in other ways, have interfered, we should expect these species to range in New Zealand up to or beyond Lake Taupo.

Examination soon shows that, of the 84 species common to Stewart and the Chathams, no less than 74 range New Zealand from end to end, while six more range from Stewart up to from 100 to 200 miles beyond Lake Taupo. This leaves only four, or less than 5 per cent., which do not reach the lake. These are Tillaea moschata and Veronica elliptica, 
both coast species which may have arrived later than the rest, by water transport; Carex appressa, which is given by Kukenthal (3) as occurring throughout New Zealand, and which consequently will not be an exception, either here or in the previous paper in which it was given as such $(7$, p. 329); and finally Pterostylis australis, which is regarded by Hooker as a variety of $P$. Banksii, whose range is the entire length of New Zealand.

Of the ferns found in the Chathams, and reaching to Lake Taupo one way and Foveaux Strait the other, 36 reach Stewart and 7 reach only to the strait, whilst Lomaria dura, which reaches only about half-way along the South Island, though it occurs in Stewart, the Snares, the Aucklands, Campbell, and the Antipodes, as well as the Chathams, is given by Cheeseman as 'a purely littoral plant, never found far from the influence of sea-spray'.

(I2) It is clear that of the many species which Stewart has in common with the other islands, those in common with the Kermadecs, which are the farthest away, will on the whole be the oldest, those in common with the Chathams probably next, and those in common with the Aucklands youngest. In other words, the first named should be the most widespread in New Zealand :

\begin{tabular}{|c|c|c|c|c|}
\hline Class. & Range. & $\begin{array}{l}\text { Stervart and } \\
\text { Kermadecs. }\end{array}$ & $\begin{array}{l}\text { Sterwart and } \\
\text { Chathams. }\end{array}$ & $\begin{array}{l}\text { Stervart and } \\
\text { Auckland's. }\end{array}$ \\
\hline I & $\mathrm{I}, \mathrm{OOI}-\mathrm{I}, 080 \mathrm{~m}$ & 22 , or $100 \%$ & 74 , or $87 \%$ & 40 , or $56 \%$ \\
\hline 2 & $881-1,000$ & - & 3 & 5 \\
\hline 3 & $761-880$ & - & 3 & 8 \\
\hline 4 & $64 I-760$ & - & - & 8. \\
\hline 5 & $5^{2} \mathrm{I}-640$ & - & 2 & 4 \\
\hline 6 & $40 \mathrm{I}-5^{20}$ & - & I & 3 \\
\hline 7 & $281-400$ & - & - & - \\
\hline 8 & $161-280$ & - & I & 3 \\
\hline & $41-160$ & - & - & - \\
\hline \multirow[t]{3}{*}{10} & $1-40$ & - & - & - \\
\hline & & 22 & 84 & 71 \\
\hline & ty (Classes I-10). & $1 \cdot 0$ & $I^{\circ} 3$ & $2 \cdot 3$ \\
\hline
\end{tabular}

Thus the Kermadec species have the maximum commonness (distribution area) possible, ranging New Zealand from end to end. The Chatham species are almost as common, and the Auckland species a good deal less so.

(I3) As the Kermadec species are the oldest, they should include the greatest proportion of wides, while the species endemic to New Zealand and the islands, which are younger, should show more in the other islands :

\section{TABLE XIV.}

Common to

Stewart and Kermadecs

" Chathams

" Aucklands
Wides.

19 , or $86 \%$

$50 \quad 59$

$26 \quad 37$
Endemic 10 Nerw Zealand and Islands.

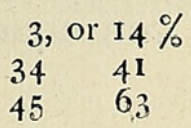




\section{ThE RELATIONSHip OF Stewart ISLAND TO INVASIONS OF PLANTS.}

We have now to go on to consider the relationship of Stewart Island to the great invasions of plants into New Zealand which were considered in my last paper $(9$, p. 355$)$. And first let us deal with the northern invasion, which probably entered, we saw, at some point (or more likely space) in the North Island not more than 400 miles south of North Cape (the island is 520 miles long).

It is at once evident that the northern invasion was very early, or that it found New Zealand at the time of its entry comparatively unobstructed with vegetation, for although it had to travel the whole length to Foveaux Strait, 1,000 miles south of North Cape, none the less a very fair proportion of its species arrived there in time to cross to Stewart before it was too late. There reach the strait, of the plants of this invasion, 5 wides and 32 endemics, and of these 3 wides and I 4 endemics cross the strait. Those which cross belong, as one would expect from predictions 2, 3, to the largest genera and families of the invasion. As a matter of fact they belong to Pittosporaceae (I genus, 19 species), Saxifragaceae (6/8), Myrtaceae (4/I8), Araliaceae (5/I5), Cornaceae (2/5), Lentibulariaceae ( $1 / 6)$, and Urticaceae (5/IO), a total of 7 families, 24 genera, and 8 I species, i. e. an average per family of 3.4 genera, and per genus of 3.3 species. The remainder of the invasion consists of 26 families, with $3^{8}$ genera and 52 species, averages of I.4 genera per family and I·3 species per genus.

To go on to the southern invasion, it is at once evident that this was either much later in New Zealand or found the ground more troublesome to traverse, as although it was mainly herbaceous, and we have some reason to suppose that herbs may travel faster than trees, of which the northern invasion was chiefly composed, and although it had its centre about 400 to 600 miles south of the other invasion, and was therefore so much the nearer to Stewart, none the less it is not so well represented there as the northern invasion. Only $5^{\mathrm{I}}$ wides out of $9 \mathrm{I}$ (at Foveaux Strait) occur in Stewart, or $5^{6}$ per cent., against 3 out of 5 , or 60 per cent., of the northern wides; and of the total of plants of the invasion, and its result in endemics, only I I 5 out of 286 cross Foveaux Strait, or 40 per cent., against I 7 out of 37 , or 45 per cent.

Had the southern invasion entered New Zealand by way of Stewart Island, one would not expect such a result, but would expect to find more species in Stewart than on the northern side of the strait. One may without any further discussion, it seems to me, come to the conclusion that the southern invasion of plants entered Stewart from the north side of Foveaux Strait, and consequently that Stewart did not lie in the direct track of that invasion. 
Again it happens that (as predicted for the northern invasion) Stewart contains chiefly representatives of the larger genera-all the families of the southern invasion are to be found. It contains $5^{6}$ genera of this invasion, represented in New Zealand by $45^{\text {I }}$ species, against $5^{2}$ unrepresented genera with $9 \mathrm{I}$ species.

We have thus made quite a number of predictions, based solely upon the hypothesis of age and area, about the flora of Stewart Island, and every one of them has proved to be correct, with a large margin. It is clear that it is fairly safe to make predictions from age and area ; in other words, the operation of this law is by far the principal factor in determining the actual geographical distribution of species about the globe prior to the advent of man. Physical barriers of course have a much greater influence in determining the actual areas occupied, but their influence is of purely negative kind, while age is positive. Local distribution, in a given district, on the other hand, is determined by the ecological conditions of that district, but unless the ecological boundary (beyond which a species cannot grow) is fairly broad and wide, it does not seem to affect seriously the total area occupied within the outer limits.

It must again be made clear, for this is a point on which many of my critics fail to understand my position, that the law must not be applied to individual species, but only to groups of allied forms. It is a law which applies to taxonomic distribution, and its operations can only be clearly made out, and disentangled from the many other causes that aid in determining geographical distribution, by taking a group of allied species. After a lapse of $x$ years a group of 20 herbaceous Compositae will occupy an area $z$; after a lapse of $y$ years a group of arboreous Dipterocarpaceae will occupy the same area $z$ in the same country, but we have no means of comparing $x$ and $y$ at present. Each, however, is governed by age and area.

Another point whose misunderstanding seems to cause difficulty for some in accepting the law, is the enormous differences between one species and another in the area occupied. They seem unable to conceive how this can come about without the operation of Natural Selection in reducing the area occupied by one of the species. In thinking over the subject they are apt to forget that the area occupied per unit time increases as the age of the species increases. So long as one only takes the diameter of the area occupied, as I have done in New Zealand, a plant when it reaches a diameter of, say, $\mathrm{I}, 000$ miles is perhaps twice the age that it was when it reached 500 . But if the species were spreading every way in untouched continental areas of uniform conditions, then, while the diameter increased

$\begin{array}{lllllll}\text { I } & 2 & 3 & 4 & 5 & 6 & 7\end{array}$


the area would increase

$$
\begin{array}{lllllll}
\text { I } & 4 & 9 & 16 & 25 & 36 & 49
\end{array}
$$

or, in other words, in equal times the increase in area occupied would be

$$
\begin{array}{llllll}
3 & 5 & 7 & 9 & \text { II } & \text { I } 3
\end{array}
$$

so that it becomes quite easily possible for a species to spread over an enormous area once that its area occupied is large. Biologists who are not accustomed to working with figures are apt to forget that the area of a circle increases with the square of its diameter.

\section{APPENDix.}

Since the above was in type, I have received from Dr. L. Cockayne, F.R.S., a most valuable letter of suggestion and criticism, and my one regret is that there is not time to think it over and incorporate the results in this paper, though I hope that further papers on New Zealand, which I have in preparation, will show its effects.

I had originaily intended to base my statements in this paper solely. on the work of Cheeseman ( $I, 2)$, but Dr. Cockayne has called my attention to the fact that his report on Stewart Island (IO) contains many additions to the flora. There are so many that it would be unpardonable to ignore it, though its incorporation really makes no difference to my final results, and does not affect in any way the correctness of the predictions here made.

The additions to the flora made in the paper referred to are:-

\section{RANUNCULACEAE}

Ranunculus + Crosbyi (endęmic)

Caltha novaezealandiae VIOLACEAE

Hymenanthera $\dagger$ dentata CAR YOPHYLLACE AE

Colobanthus + Billardieri? HYPERIC.ACEAE

Hypericum japonicum MALVACEAE

Plagianthus divaricatus TILIACEAE

Aristotelia Colensoi CORIAR̈IACEAE

Coriaria thymifolia

ROSACEAE

Potentilla anserina

Acaena + novaezealandiae

HALOR H A GIACEAE

Myriophyllum Votschii

Gunnera t prorepens arenaria?

ONAGR ACEAE

Epilobium + pallidiflorum

junceum
pictum
insulare
novaezealandiae

A $\mathrm{B} \quad \mathrm{C}$

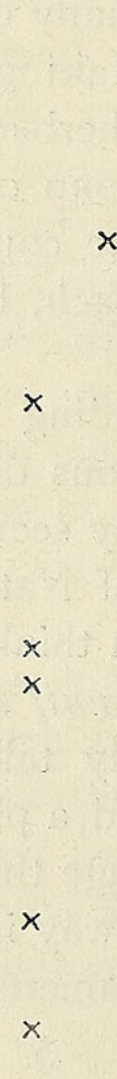
$x$
FICOIDEAE

Mesembryanthemu ausirale UMBELLIFERAE + Azorella + Cockaynei (endemic) Oreomyrrhis andicola Ligusticum + aromaticum Panax $\uparrow$ anomalum $R U B I A C E A E$

Coprosma + rotundifolia areolata ramulosa retusa COMPOSITAE†

Olearia + divaricata (endemic)! virgata

Celmisia $\uparrow$ rigida (endemic)

Gnaphalium + trinerve

Raoulia + australis glabra

Helichrysum + Loganii?

Abrotanella + linearis

Erechtites + quadridentato

Taraxacum glabratum STYLIDIACEAE

Phyllachne clavigera CAMPANULACEAE† Wahlenbergia gracilis
A B C

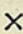


A B C

MYR SINACEAE

Phormium Cookianum

A $\mathrm{B} \quad \mathrm{C}$

Myrsine $\dagger$ chathamica (prob. introd.)

APOCYNACEAE

Parsonsia heterophylla BOR AGINACEAE

Myosotis + spathulata CONVOLVULACEAE +

Calystegia tugoriorum SCROPHULARIACEAE†

$V$ eronica + Laingii (endemic)

Ourisia + prorepens? modesta (endemic)

Euphrasiat repens LABIATAE

Meniha Cunninghamii

ILLECEBRACEAE

Scleranthus biflorus POLYGONACEAE

Muehlenbeckia complexa LORANTHACEAE

Loranthus $\uparrow$ micranthus EUPHOR BIACEAE

Euphorbia glauca

LILIACEAE†

Astelia $\uparrow$ subulata
Bulbinella Gibbsii (endemic) JUNCACEAE

Juncus † lamprocarpus CYPERACEAE†

$\times$

Eleocharis + acuta Cunninghamii

Scirpus † sulcatus

$x$

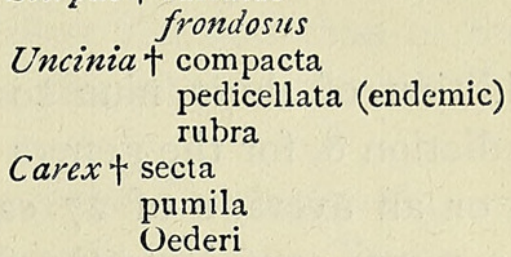

$x$

GRAMINEAE +

Agrostis † Dyeri

Deyeuxia + Billardieri

Deschampsia + Chapmanni

Agropyrum scábrum

Asprella gracilis FILICES +

Hypolepis millefolium

Lomaria + nigra

Asplenium + Lyallii

Polystichum + cystotegia adiantiforme

Of these species, $2 \mathrm{I}$ are predicted, and 56 not, a proportion considerably smaller (largely owing to the presence of so many endemics of Stewart Island) than that given at the end of the principal table above (28 against 45 per cent.). No fewer than 14 of the 32 species given as wrongly predicted on p. 33 are included in this list, so that there only remain 18 species predicted that have not been found.

The predictions given in the paragraphs numbered $I, 2,3,4,5$, and 6 remain as before, with slight numerical alterations.

In prediction 7 (Stewart Island endemics) we must add nine new endemics to the ten there mentioned, as follows:

Family (in Order of Size
in New Zealand).
I. Compositae
2. Cyperaceae
3. Scrophulariaceae
4. Gramineae
5. Orchidaceae
6. Umbelliferae
7. Ranunculaceae
8. Rubiaceae
9. Onagraceae
I0. Epacridaceae
I I. Leguminosae
I 2. Boraginaceae
I3. Juncaceae
I4. Cruciferae
15. Liliaceae

No. of Species in No. of Species in
New Zealand.1

203
II 7
109
97
57
54
45
43
31
28
25
24
24
22
20

of Species in
Sterwart.
44

34

9

30

2 I

II

8

13

8

10

$-$

7

3
Endemics.

$\{$ Olearia divaricata

$\{$ Celmisia rigida Uncinia pedicellata

S Veronica Laingii

\{ Ourisia modesta

$\{$ Azorella Cockaynei $\left\{\right.$ Aciphylla Traillii ${ }^{2}$

Ranunculus Crosbyi

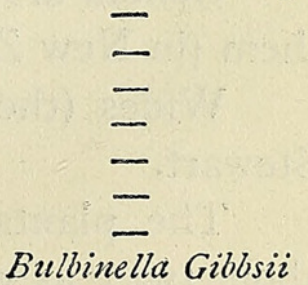

1 The new endemics must be added to these totals.

2 Regarded above as occurring in New Zealand. 
This result again emphasizes the fact that the endemics occur almost only in the very largest families (the average size of a family in New Zealand is $\mathbf{I} 5$ species), i.e., as we have explained, the families which are on the whole the oldest in New Zealand. If we add together the two lists of endemics, we find that I 7 occur in the first seven families, and only 2 in the second eight, while the 76 smaller families contain none whatever.

The addition of these nine to the list of endemics of Stewart also confirms prediction 8 , for the genera to which they belong, 9 in all, contain 249 species, or an average of 27 each, a slightly higher figure than that given for the genera containing the first ten endemics.

The other predictions given also remain as stated, with slight numerical corrections.

Nothing, therefore, in this great addition to the species found on Stewart Island compels any modification or real revision of the general thesis of this paper, and in this respect it may be compared with the revision of the figures for Ceylon which I have elsewhere published (II), and which also showed no differences in the final results.

\section{SUMMARY.}

The flora of Stewart Island is dealt with in the light of age and area as regards its taxonomic distribution. Numerous predictions are made as to what should be expected under that hypothesis, and verification is made upon the facts, all the predictions proving to be correct.

An attempt is made to predict the actual composition of the flora from what is known of the floras of the Kermadecs (I,200 miles away, at the other end of New Zealand), Chathams, and Aucklands, and 139 species of Angiosperms out of 383 are correctly predicted, and no less than 46 out of 62 ferns ( 74 per cent.), while only I 8 species are predicted that have not been found.

Verification of the other predictions shows that-

Stewart has a greater proportionate representation of families than of genera, and of genera than of species, as compared with New Zealand.

Families are represented in proportion to the number of genera contained in them (in New Zealand).

Genera are represented in proportion to the number of species in them (in New Zealand).

Wides (the oldest forms) are best represented in the flora of Stewart.

The plants of Stewart are very widely spread in New Zealand, about twice as widely as the average.

The proportional representation of ferns is greater. 
The endemics of Stewart are in the largest (in general, oldest) families of New Zealand.

The endemics of Stewart are in the larger (older) genera of New Zealand.

The Kermadec, Chatham, and Auckland Islands have proportionately more in common with Stewart than they have with New Zealand itself, although they are nearer to New Zealand than to Stewart.

All species that occur both in the Chathams and the Aucklands are also found in Stewart.

Species common to Stewart and the Chathams (84) range in New Zealand, with 4 (really 3 ) exceptions, up to Lake Taupo or beyond (in the North Island), i.e. to the circumference of the circle passing through Stewart and the Chathams.

The species common to Stewart and the Kermadecs (22) are most widespread in New Zealand (rarity $\mathbf{I} \cdot 0$, the minimum), those common to Stewart and the Chathams next, and those to Stewart and the Aucklands least so.

The plants common to Stewart and the Kermadecs, being the oldest, show the greatest proportion of wides, while endemic forms show in increasing proportion in the plants common to Stewart and the Chathams, or Stewart and the Aucklands.

The relationship of Stewart to the two great invasions of plants into New Zealand is then considered, and it is shown that the northern invasion was perhaps the earlier, and that Stewart did not lie in the track of the southern invasion, but received the plants thereof from the north side of Foveaux Strait. In each invasion the plants which occur in Stewart are selected from the largest families and genera.

Finally, it is pointed out that as so many predictions may be successfully based upon age and area alone, the operation of this factor must be the principal positive determining cause in geographical distribution, while the operation of barriers is the principal negative cause. Some difficulties which various workers have experienced in thinking of the hypothesis are also pointed out, notably that the area occupied, in the absence of barriers or other causes of limitation, increases with the square of the diameter, the latter probably increasing uniformly with the passage of time. 


\section{BIBLIOGRAPHY.}

1. Cheeseman: Manual of the New Zealand Flora. Wellington, 1906.

2. - On the Systematic Botany of the Islands to the South of New Zealand, in Chilton's 'Subantarctic Islands of New Zealand', vol. ii, p. 389. Wellington, I909.

3. Kukenthal: Cyperaceae-Caricoideae, in 'Das Pflanzenreich'. Leipzig, 1909.

4. Marshall : Geology of New Zealand. Wellington, I 912.

5. Petrie : Gramina of the Subantarctic Islands of New Zealand, in Chilton. 1.c., p. 472.

6. Willis : Relative Age of Endemic Species. Ann. Bot., vol. xxxi, 19I7, p. I89.

7. - : Distribution of the Plants of the Outlying Islands of New Zealand. 1.c., p. 327.

8. - Further Evidence for Age and Area. 1. c., p. 335.

9. - The Sources and Distribution of the New Zealand Flora. 1. c., vol. xxxii, 1918, p. 339.

10. Cockayne : Report on a Botanical Survey of Stewart Island (N.Z. Dept. of Lands). Wellington, 1909 .

11. Willis: The Endemic Flora of Ceylon (correction). Proc. Roy. Soc, B., vol. lxxxix, 1916. 


\section{$2 \mathrm{BHL}$ Biodiversity Heritage Library}

Willis, J. C. 1919. "The flora of Stewart Island (New Zealand): a study in taxonomic distribution." Annals of botany 33, 23-46.

https://doi.org/10.1093/oxfordjournals.aob.a089701.

View This Item Online: https://www.biodiversitylibrary.org/item/235681

DOI: https://doi.org/10.1093/oxfordjournals.aob.a089701

Permalink: https://www.biodiversitylibrary.org/partpdf/320243

\section{Holding Institution}

Smithsonian Libraries

\section{Sponsored by}

Biodiversity Heritage Library

\section{Copyright \& Reuse}

Copyright Status: Not in copyright. The BHL knows of no copyright restrictions on this item.

This document was created from content at the Biodiversity Heritage Library, the world's largest open access digital library for biodiversity literature and archives. Visit BHL at https://www.biodiversitylibrary.org. 